\title{
CLINICAL PROFILE AND MANAGEMENT OF LOWER LIMB VARICOSE VEINS
}

\author{
Hemant B. Janugade1, Bhushan Pralhad Patil2, Neville Hoshedar Tata3 ${ }^{3}$ Harshawardhan Vidyasagar Saygaonkar4, \\ Deepali Hemant Janugade, Vivek Dokania ${ }^{6}$
}

1Professor, Department of General Surgery, Krishna Institute of Medical Sciences University, Karad, Maharashtra. ${ }^{2}$ Resident, Department of General Surgery, Krishna Institute of Medical Sciences University, Karad, Maharashtra. ${ }^{3}$ Resident, Department of General Surgery, Krishna Institute of Medical Sciences University, Karad, Maharashtra. ${ }^{4}$ Resident, Department of General Surgery, Krishna Institute of Medical Sciences University, Karad, Maharashtra. ${ }^{5}$ Assistant Professor, Department of Obstetrics and Gynaecology, Krishna Institute of Medical Sciences University, Karad, Maharashtra. ${ }^{6}$ Resident, Department of ENT, Krishna Institute of Medical Sciences University, Karad, Maharashtra.

\section{ABSTRACT}

\section{BACKGROUND}

The first written reference of varicose veins appears to be the Ebers Papyrus dated 1550 B.C. It is one of the oldest documented pathological conditions in existence today. This study deals with its aetiology, pathology and the different modes of treatment and their efficacy in detail.

\section{MATERIALS AND METHODS}

50 patients with lower limb varicose veins admitted in the Department of General Surgery, KIMS, Karad from October 2014 to July 2016 were included in the study. All patients were subjected to detailed history taking, clinical examination and relevant investigations. Depending on the merits of the disease, appropriate treatment options are selected. All the results are evaluated and analysed by comparing with other standard results.

\section{RESULTS}

In this study, there were 34 males and 16 females (M:F = 2.1:1). Most of the patients were between $20-50$ yrs. of age ( $80 \%$ ); $56 \%$ of patients had occupations, which involved prolonged standing. In this study, $48 \%$ of patients had positive family history. The most common presenting complaint was prominent veins (100\%) and pain in 54\% of patients. Right limb was involved in $38 \%$ and the left limb involved in 52\% of patients. Long saphenous vein was involved in $98 \%$ of patients, the second commonest being perforators which were involved in $86 \%$ of patients. Majority of the patients had combined saphenofemoral and perforator incompetence (70\%). Duplex ultrasound was very accurate in diagnosing perforator incompetence. Treatment was depended upon the individual cases. In patients with venous ulcers Bisgaard's method of treatment was followed till the ulcer heals and then the patient was subjected to further definitive treatment. SFJ ligation with stripping was the most common surgery performed. Among post-operative complications, wound infection was the most common (14\%).

\section{CONCLUSION}

This study showed that the prevalence of varicose veins of lower limb have a male predominance and is more common in younger age group. Family history and occupation are important contributing factors in the development of lower limb varicose veins. Left lower limb involvement is more than the right. Duplex ultrasound is the investigation of choice of lower limb varicose veins. Saphenofemoral flush ligation with stripping is very effective in the treatment of varicose veins.

\section{KEYWORDS}

Varicose Veins, Lower Limb Pain, Venous Ulcer, Haemorrhage, Aetiology, Duplex Ultrasound, Saphenofemoral Flush Ligation, Stripping, Complications.

HOW TO CITE THIS ARTICLE: Janugade HB, Patil BP, Tata NH, et al. Clinical profile and management of lower limb varicose veins. J. Evolution Med. Dent. Sci. 2017;6(20):1615-1622, DOI: 10.14260/Jemds/2017/354

\section{BACKGROUND}

Varicose veins and their associated symptoms and complications constitute the most common chronic vascular disorder of the lower limb. The term varicose is derived from the Latin word meaning dilated. Varicose veins is defined as dilated, tortuous and elongated veins.

Financial or Other, Competing Interest: None.

Submission 09-01-2017, Peer Review 22-02-2017,

Acceptance 01-03-2017, Published 20-03-2017.

Corresponding Author:

Dr. Bhushan Pralhad Patil,

Flat No. 4, Chintamani Apartments,

Near Atul Bhosales Bungalow,

Koyna Vasahat, Malkapur,

Karad-415539.

E-mail: dr.bhushanpatil999@gmail.com

DOI: $10.14260 /$ jemds $/ 2017 / 354$
Varicose veins are a common medical condition present in at least $10 \%$ of the general population. ${ }^{1}$ The symptoms of varicose veins range from asymptomatic varicose veins to more severe complications, such as ulceration and bleeding.

Varicose veins may cause significant morbidity including dermatitis, ankle oedema, spontaneous bleeding, superficial thrombophlebitis, lipodermatosclerosis and ulceration.

Varicose veins were recognised pre-historically and many inventions were made regarding the diagnosis and treatment of varicose veins by many phlebologists including many bandaging techniques, ligation and stripping of veins. The attention was mainly towards the mechanical effects of the varicosity rather than the basic cause. It is only in the recent past that considerable knowledge has been gained concerning the anatomy of the venous system of the leg, the physiological mechanism of venous return to the heart 
against gravity and pathology of the disorder, which has led to many newer modalities of investigations and treatment.

The Doppler ultrasound and duplex imaging have become the mainstay of investigations in the diagnosis of chronic venous insufficiency. ${ }^{2}$

The treatment options for varicose veins include Trendelenburg operation, Stripping, Subfascial ligation of perforators, Laser, Sclerotherapy, Subfascial endoscopic perforator surgery and Radiofrequency ablation. In the recent past, minimally invasive procedures are replacing the more invasive procedures.

The search for more effective means of diagnosing and treating varicose veins and prevention and management of its complications continues and this article aims at studying the distribution, pathology, clinical features, various modes of investigations and overall management of varicose veins of lower limbs.

\section{Aims and Objectives}

1. To study the distribution, pathology and clinical features of varicose veins of lower limbs in rural areas.

2. To study the various modes of investigations and management of varicose veins in the lower limbs effectively and to prevent complications.

\section{MATERIALS AND METHODS}

\section{Source of Data}

This study includes all the patients admitted with lower limb varicose veins to Surgical Department of Krishna Institute of Medical Sciences, Karad from October 2014 to June 2016.

\section{Sample Size}

Total number of patients were 50. All the cases were admitted to the hospital and evaluated by taking detailed history and by carrying out thorough clinical examination. The findings were recorded in clinical proforma.

\section{Collection of Data}

\section{Inclusion Criteria}

General Criteria for Selection of the Cases in the Study were as Follows

1. Symptomatic varicose veins with symptoms of aching, heaviness and cramps.

2. Complications of venous stasis such as pigmentation, dermatitis, ulceration and superficial thrombophlebitis.

3. Large varicosities subject to trauma.

4. Cosmetic concern.

\section{Specific Criteria - Patients with Primary Varicosities of}

1. Long Saphenous vein.

2. Short Saphenous vein.

3. Perforator incompetence.

\section{Exclusion Criteria}

All those who were treated on outpatient basis were not included in the study. Patient with secondary varicose veins due to venous obstruction were also not included in the study.

Informed consent was obtained from each patient before any investigations. Thorough physical examination was done by investigator himself by using the aforementioned clinical tests and confirmed by doing special non-invasive investigations such as Duplex ultrasound.

\section{Investigations}

Routine Investigations and Special Investigations Like

1. Doppler of venous system.

2. Duplex scanning for accurate diagnosis and planning of treatment.

3. Plain x-ray of affected part in case of venous ulcer, particularly in presence of signs of infection for evidence of periostitis.

\section{Treatment}

\section{Conservative Treatment}

A course of conservative treatment was given whenever indicated with rest, antibiotics and elastocrepe bandage.

\section{Surgical Treatment}

Following surgical treatment were carried out in our Institute.

1. Trendelenburg's operation.

2. Stripping of long saphenous vein.

3. Subfascial or extrafacial ligation of perforators.

4. Multiple stab avulsions of long saphenous vein.

5. Saphenopopliteal junction ligation.

\section{Data Analysis}

The postoperative course was noted; minor complications were attended and treated accordingly. Patients were followed up further. Final outcome evaluated. All the clinical data of each patient were recorded in the pre-coded clinical proforma designed for the study.

Important data pertaining to each case is shown in the master chart and the results are analysed by comparing with standard results of known Authors. Ethical clearance was taken from our Institute for the study.

\section{RESULTS}

Varicose veins appear to be common among the general population, but the incidence of hospital admission does not project the true prevalence rate. The hospitalised group is only a tip of the iceberg. An epidemiological study can give its true incidence in the general population.

A total of 50 patients ( 55 number of limbs) with primary varicose veins admitted in surgical ward of Krishna Institute of Medical Sciences, Karad, were studied and following findings were noted and analysed.

\section{Sex Distribution}

The Indian male appears to be more prone to the development of varicosity of veins of lower limb than the females.

\begin{tabular}{|c|c|c|}
\hline No. of Cases Studied & No. of Cases & Percentage \\
\hline Males & 34 & $68 \%$ \\
\hline Females & 16 & $32 \%$ \\
\hline \multicolumn{2}{|c|}{ Table 1. Sex Distribution } \\
\hline
\end{tabular}




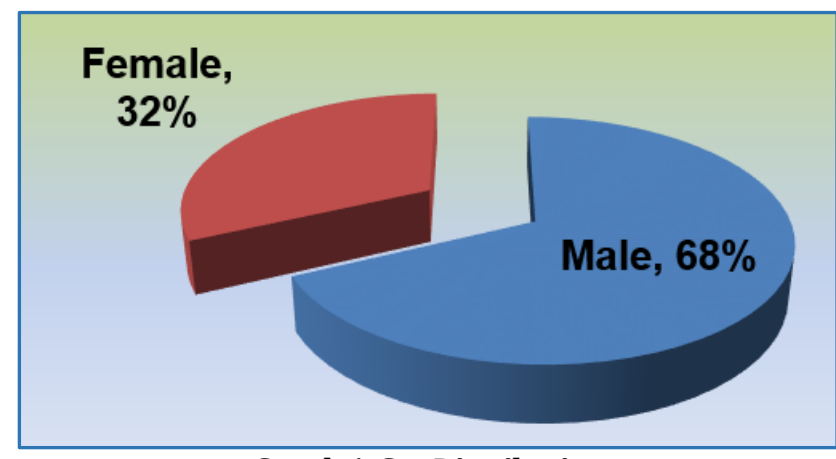

Graph 1. Sex Distribution

\begin{tabular}{|c|c|c|c|c|}
\hline Sex & $\begin{array}{c}\text { No. of } \\
\text { Patients }\end{array}$ & $\%$ & $\begin{array}{c}\text { Changes C J } \\
\text { et al }\end{array}$ & $\begin{array}{c}\text { AHM Dur, AJC } \\
\text { Mackaay et al } \\
\text { (\%) }^{\mathbf{3}}\end{array}$ \\
\hline Male & 34 & $68 \%$ & 18.12 & 26.66 \\
\hline Female & 16 & $32 \%$ & 81.88 & 73.24 \\
\hline \multicolumn{4}{|c|}{ Table 2. Sex Distribution (Comparison) } \\
\hline
\end{tabular}

In the present study, 16 cases were female out of total 50 patients. It is very low compared to the Western studies. These females sought treatment for symptoms due to varicosities rather than cosmetic reason. Most probably Indian women cover their limbs with saree and hence they are not much bothered about the appearance of dilated veins.

\section{The Age Distribution}

The age distribution is characteristically between $20-50$ years. This group includes $80 \%$ of cases. The youngest patient is of the age of 20 years and the oldest at 70 years.

These findings are consistent with the studies of other workers.

\begin{tabular}{|c|c|c|}
\hline Age (Years) & $\begin{array}{c}\text { Number of } \\
\text { Patients }\end{array}$ & Percentage \\
\hline $11-20$ & 1 & $02 \%$ \\
\hline $21-30$ & 17 & $34 \%$ \\
\hline $31-40$ & 11 & $22 \%$ \\
\hline $41-50$ & 11 & $22 \%$ \\
\hline $51-60$ & 6 & $12 \%$ \\
\hline $61-70$ & 4 & $8 \%$ \\
\hline \multicolumn{3}{|c|}{ Table 3. Age Distribution } \\
\hline
\end{tabular}

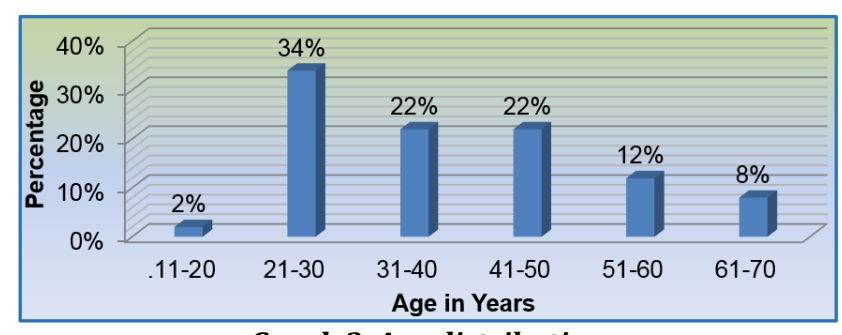

Graph 2. Age distribution

\begin{tabular}{|c|c|c|c|c|}
\hline $\begin{array}{c}\text { Age } \\
\text { (Years) }\end{array}$ & $\begin{array}{c}\text { Lateef } \\
\text { (1971) }^{\mathbf{4}}\end{array}$ & $\begin{array}{c}\text { Fegan } \\
\mathbf{( 1 9 7 2 )}^{\mathbf{5}}\end{array}$ & $\begin{array}{c}\text { Ratkal } \\
\mathbf{( 1 9 8 0 )}^{\mathbf{6}}\end{array}$ & $\begin{array}{c}\text { Present } \\
\text { Series }\end{array}$ \\
\hline Below 20 & $05 \%$ & $5 \%$ & $06 \%$ & $0 \%$ \\
\hline $20-40$ & $65 \%$ & $75 \%$ & $72 \%$ & $58 \%$ \\
\hline Above 40 & $30 \%$ & $20 \%$ & $22 \%$ & $42 \%$ \\
\hline \multicolumn{4}{|c|}{ Table 4. Age Distribution (Comparison Study) } \\
\hline
\end{tabular}

Majority of the patients in the study were less than 50 years. So, it is the disease which affects the youth and the bread-earning members of the society.

\section{Occupation}

Occupation has a definite role to play as a causative factor. Varicose veins are common in person, whose occupation demands prolonged standing. It is the part of the penalty for adopting an erect posture.

\begin{tabular}{|c|c|c|c|}
\hline Occupation & $\begin{array}{c}\text { Lateef } \\
\text { (1971) }^{4}\end{array}$ & $\begin{array}{c}\text { Ratkal } \\
\text { (1980) }^{6}\end{array}$ & $\begin{array}{c}\text { Present } \\
\text { Series }\end{array}$ \\
\hline $\begin{array}{c}\text { Occupation } \\
\text { Involving } \\
\text { Prolonged } \\
\text { Standing }\end{array}$ & $35 \%$ & $44 \%$ & $56 \% 1$ \\
\hline \multicolumn{3}{|c|}{ Table 5. Comparison Study of } \\
Occupation versus Varicose Veins \\
\hline
\end{tabular}

In this study, $56 \%$ of patients belong to the group whose occupation involved prolonged standing.

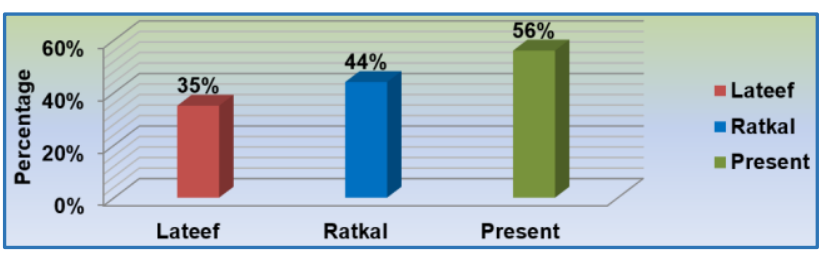

Graph 3. Occupation involving Prolonged Standing

\section{Family History}

Among 50 cases studied, 24 cases had family history of close relatives suffering from varicose veins. The occurrence of varicose veins in several members of the family suggests that hereditary factors may be an important cause of varicosity. Many other worker's studies have agreed with this, but in all studies relatives, were not assessed clinically; only importance was given to the history furnished by the patient.

\begin{tabular}{|c|c|c|}
\hline Varicose Vein & No. of Cases & Percentage \\
\hline Present & 24 & $48 \%$ \\
\hline Absent & 27 & $54 \%$ \\
\hline \multicolumn{2}{|c|}{ Table 6. Family History of Varicose Vein } \\
\hline
\end{tabular}

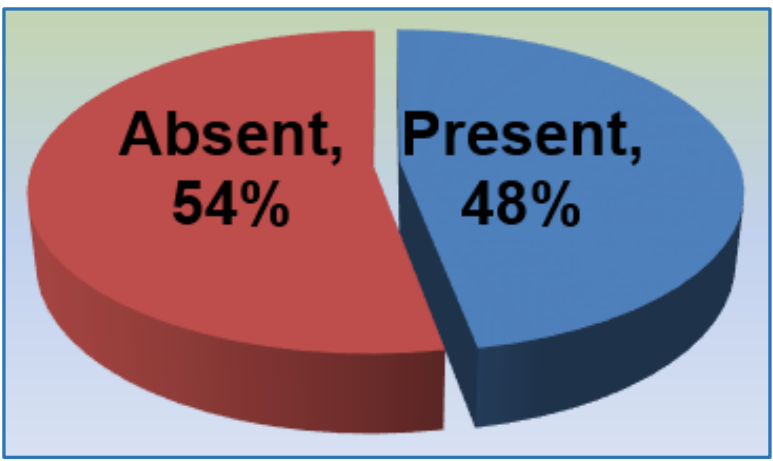

Graph 4. Family History of Varicose Vein

\begin{tabular}{|c|c|c|}
\hline Family History & Present Study & $\begin{array}{c}\text { B. B. Komsuoglu- } \\
\mathbf{1 9 9 4 7}^{\mathbf{7}}\end{array}$ \\
\hline Total No. of Patients & 50 & 312 \\
\hline Present & 24 & 154 \\
\hline Percentage & $48 \%$ & $49.4 \%$ \\
\hline \multicolumn{2}{|c|}{ Table 7. Family History (Comparative Study) } \\
\hline
\end{tabular}


In this study $48 \%$ of patients had positive family history, which is one of the important risk factor in the development of varicose veins.

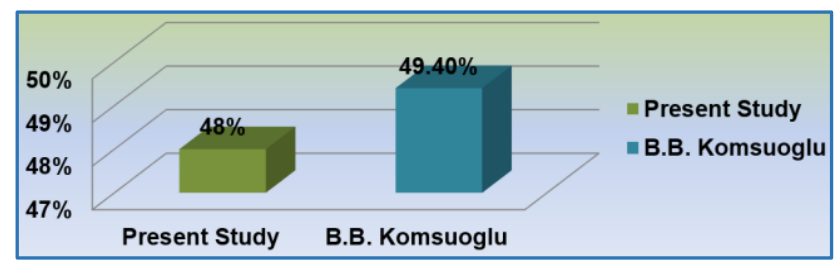

Graph 5. Family History (Comparative Study)

\section{Clinical Manifestations}

\begin{tabular}{|c|c|c|c|c|}
\hline \multirow[b]{2}{*}{ Symptoms } & \multicolumn{2}{|c|}{ Present Series } & \multirow{2}{*}{$\begin{array}{c}\text { Rudofsky G. } \\
\text { Langen Becks } \\
\text { Arch Chir (\%) }\end{array}$} & \multirow{2}{*}{$\begin{array}{c}\text { O'Shaug } \\
\text { hnessy } \\
\text { M et al } \\
(\%)^{9}\end{array}$} \\
\hline & $\begin{array}{c}\text { No. of } \\
\text { Patients }\end{array}$ & $\% \mathrm{C}$ & & \\
\hline Prominent Veins & 50 & 100.00 & 90.00 & 92.00 \\
\hline $\begin{array}{c}\text { Prominent Veins } \\
\text { and Pain }\end{array}$ & 27 & 54.00 & 30.00 & 54.00 \\
\hline $\begin{array}{c}\text { Prominent Veins } \\
\text { and Oedema }\end{array}$ & 29 & 58.00 & 52.00 & 62.00 \\
\hline $\begin{array}{c}\text { Pigmentation and } \\
\text { Lipodermatoscler } \\
\text { osis }\end{array}$ & 14 & 28.00 & 13.00 & 22.00 \\
\hline Venous Ulceration & 6 & 12.00 & 9.00 & 14.00 \\
\hline $\begin{array}{c}\text { Previous History } \\
\text { of DVT }\end{array}$ & 0 & 0 & 0 & 5.00 \\
\hline
\end{tabular}

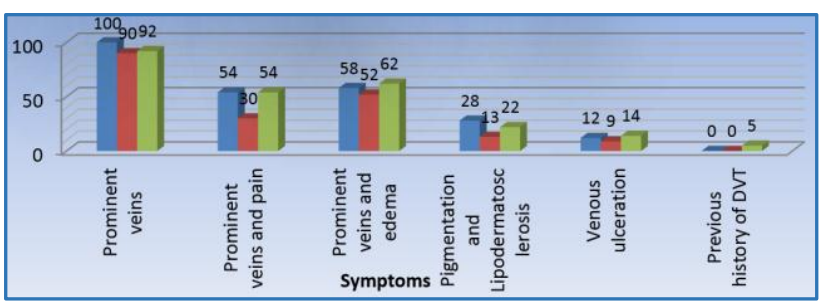

Graph 6. Clinical Manifestations

Almost all patients had prominent varicosities as common symptom associated with other manifestations and complications of varicose veins. Cosmetic appearance was the commonest presenting complaint, which favours with the other comparative studies.

\section{CEAP Classification}

\begin{tabular}{|c|c|c|}
\hline Class & Limbs & Percentage \\
\hline 0 & 0 & $0 \%$ \\
\hline 1 & 0 & $0 \%$ \\
\hline 2 & 19 & $38 \%$ \\
\hline 3 & 14 & $28 \%$ \\
\hline 4 & 8 & $16 \%$ \\
\hline 5 & 3 & $6 \%$ \\
\hline 6 & 6 & $12 \%$ \\
\hline \multicolumn{2}{|c|}{ Table 9. Clinical Class of CEAP } \\
\hline
\end{tabular}

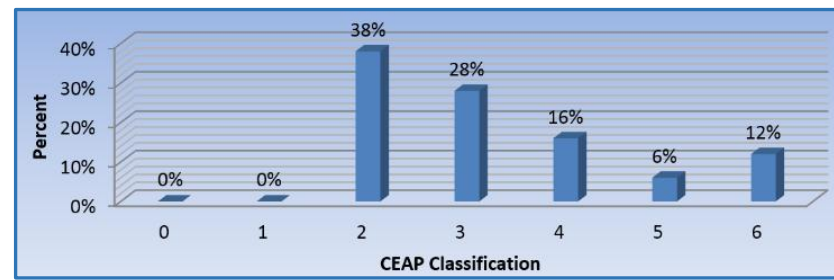

Graph 7. Clinical Class of CEAP

The majority of the patients (38\%) belonged to clinical class II of CEAP classification. The $62 \%$ of patients had complications of varicose veins.

\section{Limb Involvement}

\begin{tabular}{|c|c|c|c|}
\hline Limb Involved & \multicolumn{2}{|c|}{ Present Series } & $\begin{array}{c}\text { A.H.M. Dur, A.J.C. } \\
\text { Mackaay et al }{ }^{3}\end{array}$ \\
\hline Right & 19 & $38 \%$ & $43.48 \%$ \\
\hline Left & 26 & $52 \%$ & $56.42 \%$ \\
\hline Both & 05 & $10 \%$ & $0.0 \%$ \\
\hline \multicolumn{4}{|c|}{ Table 10. Limb Involvement } \\
\hline
\end{tabular}

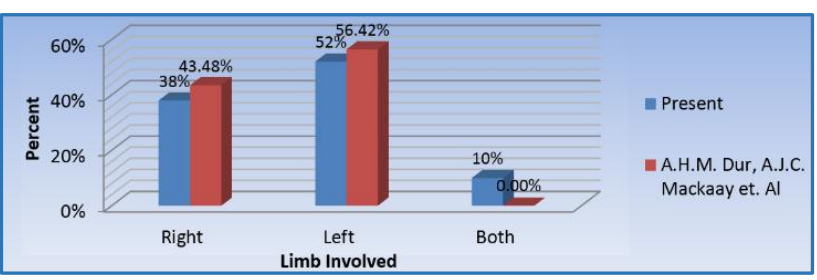

Graph 8. Limb Involvement

In the present study, right limb involvement of $38 \%$ and the left limb involvement of $52 \%$, favourably compares with the study conducted by A.H.M. Dur, A.J.C. Mackaay et al. The cause for the increased incidence of left side is not known. This is probably because that the loaded left colon constantly compresses the left iliac veins, the left common iliac artery crossing over the left common iliac vein and the longer course traversed by the left iliac veins. In the present study, bilateral varicose veins were seen in 5 patients $(10 \%)$.

\section{Venous System Involved}

\begin{tabular}{|c|c|c|c|}
\hline System Involved & Limbs & $\mathbf{\%}$ & $\begin{array}{c}\text { Al-Mulhim et al, King } \\
\text { Fahad Hospital (\%) }\end{array}$ \\
\hline Long Saphenous Vein & 49 & $98 \%$ & 68.42 \\
\hline Short Saphenous Vein & 9 & $18 \%$ & 7.02 \\
\hline Both & 8 & $16 \%$ & $24.56 \%$ \\
\hline Perforators & 43 & $86 \%$ & $87.29 \%$ \\
\hline \multicolumn{3}{|c|}{ Table 11. Venous System Involved } \\
\hline
\end{tabular}

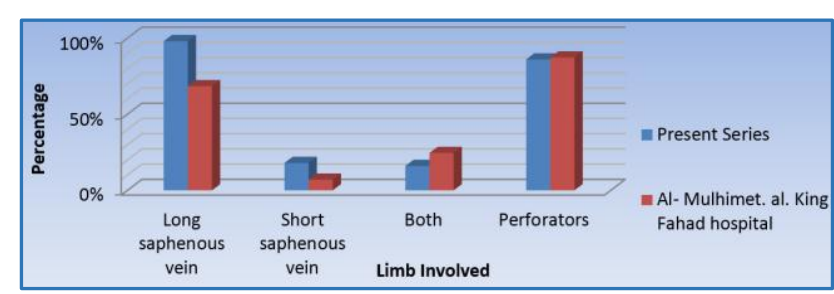

Graph 9. Venous System Involved 
As the long saphenous vein extends along the whole length of the limb, it bears the brunt of the erect posture. The long saphenous vein was involved in $98 \%$ of cases, the second victim being the perforators, which was involved in $88 \%$ of cases. The short saphenous vein involvement in the present series was $18 \%$. Other workers also confirm this fact.

\begin{tabular}{|c|c|c|}
\hline Sites of Incompetence & $\begin{array}{c}\text { Number of } \\
\text { Patients }\end{array}$ & Percentage \\
\hline Saphenofemoral Alone & 05 & $10 \%$ \\
\hline Saphenofemoral + Perforators & 35 & $70 \%$ \\
\hline $\begin{array}{c}\text { Saphenofemoral + } \\
\text { Saphenopopliteal + Perforator } \\
\text { Incompetence }\end{array}$ & 07 & $14 \%$ \\
\hline Perforators Alone & 01 & $02 \%$ \\
\hline $\begin{array}{c}\text { Saphenofemoral + } \\
\text { Saphenopopliteal Incompetence }\end{array}$ & 01 & $02 \%$ \\
\hline Saphenopopliteal Incompetence & 01 & $02 \%$ \\
\hline \multicolumn{2}{|c|}{ Table 12. Sites of Incompetence } \\
\hline \multicolumn{2}{|c|}{} \\
\hline
\end{tabular}

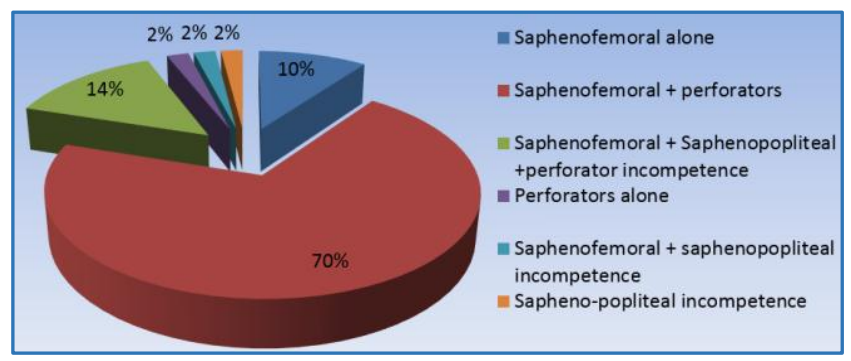

Graph 10. Sites of Incompetence

Most patients (70\%) had saphenofemoral and perforator incompetence. Isolated perforator incompetence was seen only in $2 \%$ of patients; $14 \%$ patients present with combined saphenofemoral, saphenopopliteal and perforator incompetence.

\begin{tabular}{|c|c|c|c|c|c|c|c|}
\hline $\begin{array}{c}\text { CEAP } \\
\text { Class }\end{array}$ & Limbs & SFI & SFI + PI & $\begin{array}{c}\text { SFI +SPI } \\
+ \text { PI }\end{array}$ & SFI +SPI & SPI & PI \\
\hline 0 & 0 & 0 & 0 & 0 & 0 & 0 & 0 \\
\hline 1 & 0 & 0 & 0 & 0 & 0 & 0 & 0 \\
\hline 2 & 19 & 2 & 13 & 1 & 1 & 1 & 1 \\
\hline 3 & 14 & 3 & 9 & 2 & 0 & 0 & 0 \\
\hline 4 & 8 & 0 & 5 & 3 & 0 & 0 & 0 \\
\hline 5 & 3 & 0 & 2 & 1 & 0 & 0 & 0 \\
\hline 6 & 6 & 0 & 6 & 0 & 0 & 0 & 0 \\
\hline \multicolumn{7}{|c|}{ Table 13. Correlation between } \\
\hline
\end{tabular}

The patients with higher grade of clinical CEAP classification had combined valvular incompetence. All the patients with ulcers had perforator incompetence.

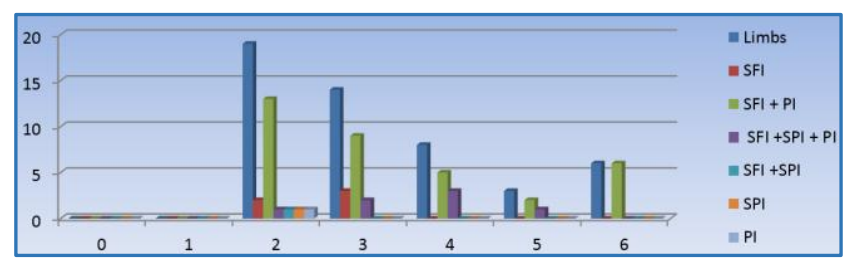

Graph 11. Correlation between

CEAP Class and Sites of Incompetence
Sites of Perforator Incompetence

\begin{tabular}{|c|c|c|}
\hline Sites of Perforator & $\begin{array}{c}\text { No. of } \\
\text { Patients }\end{array}$ & Percentage \\
\hline Above Knee Perforators & 01 & $02.3 \%$ \\
\hline Below Knee Perforators & 14 & $32.5 \%$ \\
\hline Lower Leg and Ankle Perforators & 06 & $13.9 \%$ \\
\hline $\begin{array}{c}\text { Multiple Perforator } \\
\text { Incompetence }\end{array}$ & 22 & $51.1 \%$ \\
\hline
\end{tabular}

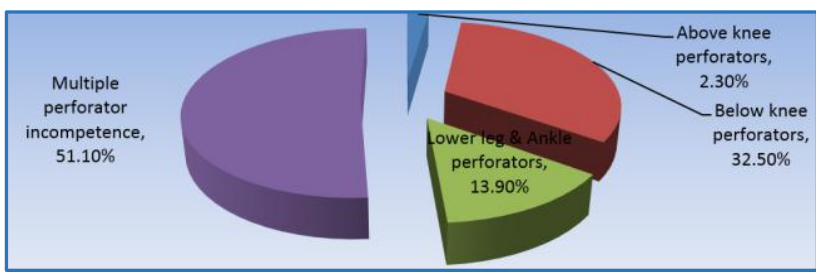

Graph 12. Sites of Perforator Incompetence

\section{Duplex Ultrasound}

\begin{tabular}{|c|c|c|}
\hline Findings & $\begin{array}{c}\text { Clinical } \\
\text { Examination }\end{array}$ & $\begin{array}{c}\text { Duplex } \\
\text { USG }\end{array}$ \\
\hline Saphenofemoral Incompetence & 48 & 48 \\
\hline Saphenopopliteal Incompetence & 9 & 9 \\
\hline \multicolumn{2}{|c|}{ Perforator Incompetence } \\
\hline Above Knee Perforators & 00 & 01 \\
\hline Below Knee Perforators & 13 & 14 \\
\hline Lower Leg Perforators & 06 & 06 \\
\hline Multiple Perforators & 20 & 22 \\
\hline Deep Venous Thrombosis & 0 & 0 \\
\hline Table 15. Correlation between Clinical \\
Examination v/s Duplex Ultrasound \\
\hline
\end{tabular}

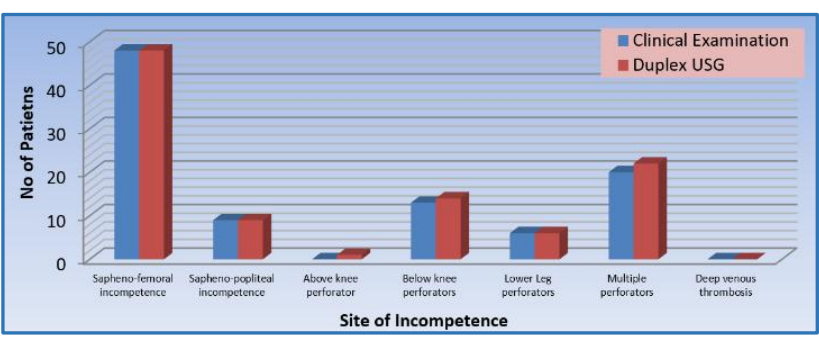

Graph 13. Clinical Examination $v / s$ Duplex Ultrasound Site of Incompetence

Duplex ultrasound was required to accurately diagnose perforator incompetence in 4 patients.

\section{Surgical Procedures}

\begin{tabular}{|c|c|c|}
\hline Surgical Procedures & Limb & Percentage \\
\hline $\begin{array}{l}\text { Saphenofemoral Flush Ligation + } \\
\text { Stripping }\end{array}$ & 22 & $44 \%$ \\
\hline $\begin{array}{l}\text { Saphenofemoral Flush Ligation + } \\
\text { Stripping + Multiple Stab Avulsion }\end{array}$ & 04 & $08 \%$ \\
\hline $\begin{array}{l}\text { Saphenofemoral Flush Ligation + } \\
\text { Stripping + Subfascial Ligation }\end{array}$ & 14 & $28 \%$ \\
\hline $\begin{array}{c}\text { Saphenofemoral Flush Ligation }+ \\
\text { Stripping* + Saphenopopliteal Ligation }\end{array}$ & 03 & $06 \%$ \\
\hline $\begin{array}{l}\text { Saphenofemoral Flush Ligation + } \\
\text { Stripping* + Saphenopopliteal Ligation } \\
+ \text { Subfascial Ligation }\end{array}$ & 05 & $10 \%$ \\
\hline Saphenopopliteal Ligation Alone & 01 & $02 \%$ \\
\hline Multiple Stab Avulsion Alone & 01 & $02 \%$ \\
\hline
\end{tabular}




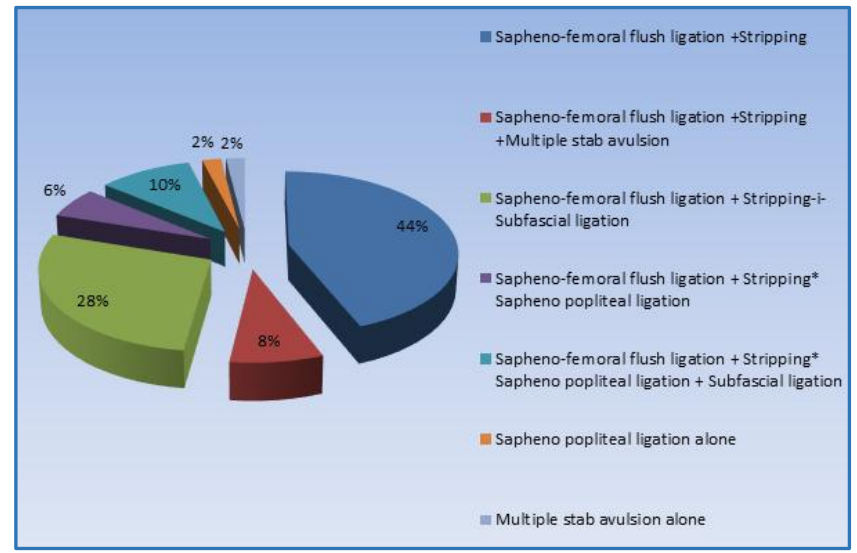

Graph 14. Surgical Procedure Performed

SFFL - Saphenofemoral Flush Ligation

STRP - Stripping

SFL - Subfascial Ligation

MSA - Multiple Stab Avulsion

SPL - Saphenopopliteal Ligation

\begin{tabular}{|c|c|c|}
\hline Procedures & $\begin{array}{c}\text { Present } \\
\text { Study }\end{array}$ & $\begin{array}{c}\text { S.K. Sahu, S Bhushan, } \\
\text { P.K. Sacha, 201211 }\end{array}$ \\
\hline $\begin{array}{c}\text { Trendelenburg } \\
\text { Operation + } \\
\text { Stripping }\end{array}$ & $44 \%$ & $42.85 \%$ \\
\hline \multicolumn{2}{|c|}{ Table 17. Comparative Study of Treatment of Varicose } \\
Veins
\end{tabular}

Both studies showed that Trendelenburg's operation with stripping offered very effective results.

\section{Complications}

\begin{tabular}{|c|c|c|}
\hline Complications & $\begin{array}{c}\text { Number of } \\
\text { Patients }\end{array}$ & Percentage \\
\hline Wound Infection & 07 & $14 \%$ \\
\hline Haematoma & 04 & $08 \%$ \\
\hline Saphenous Neuritis & 04 & $08 \%$ \\
\hline Wound Dehiscence & 03 & $06 \%$ \\
\hline Lymphorrhoea & 02 & $04 \%$ \\
\hline Femoral Vein Injury & 0 & 0 \\
\hline Femoral Artery Injury & 0 & 0 \\
\hline Deep Vein Thrombosis & 0 & 0 \\
\hline Pulmonary Embolism & 0 & 0 \\
\hline \multicolumn{2}{|c|}{ Table 18. Complications of Surgery } \\
\hline
\end{tabular}

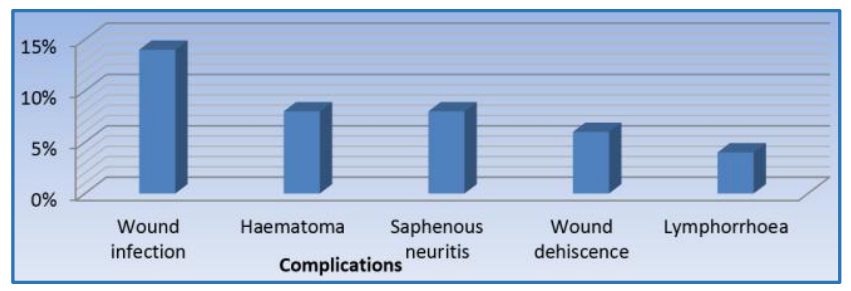

Graph 15. Complications

\begin{tabular}{|c|c|}
\hline Complications & Percentage \\
\hline Femoral Vein Injury & 1 \\
\hline Femoral Artery Injury & 0.02 \\
\hline Deep Vein Thrombosis & 0.15 \\
\hline Pulmonary Embolism & 0.06 \\
\hline \multicolumn{2}{|c|}{ Table 19. Hagmuller G.W. and } \\
Langenbecks Arch Chis Study \\
\hline
\end{tabular}

In the present study, some minor complications occurred which were managed conservatively. The study conducted by Hagmuller G. M. showed incidence of some major complications which are very rare and none of which occurred in the present study group.

\section{DISCUSSION}

Varicosity of the lower limb is a common clinical problem. Varicosities often starts early in life, but assume a silent course for variable length of time before they develop complications due to venous hypertension.

\section{Sex Distribution}

The male sex appears to be more prone to the development of varicosity of lower limb veins than the females. Though the Western study show a clear female predominance (Male: Female $=1: 5), 13,14$ the present study showed Male: Female ratio of 2.1: 1. It may be because they do not undergo the occupational hazards of that of males like prolonged standing, physical stress involving increased intra-abdominal pressure.

\section{Age Distribution}

The varicose veins are more predominant in the age group of 20 - 50 years. So it affects the bread-earning members of the family causing socioeconomic problems. In the present study, about $80 \%$ of patients belonged to this age group. 15,4

\section{Occupation}

Varicose veins are more common in persons, whose occupation force them to stand for prolonged hours. In the present study about $56 \%$ of patients had occupations, which involved prolonged standing like farmer, policemen, bus conductor, etc.

\section{Family History}

The occurrence of varicose veins in several members of the family suggests the hereditary factors may be an important cause of varicosity. In the present study, $48 \%$ of the patients had family history of varicose veins.

\section{Clinical Features}

Almost all the patients $(100 \%)$ had prominent veins as the presenting complaint. Pain was present in about $54 \%$ of patients, oedema in $58 \%$ of patients, pigmentation and lipodermatosclerosis in $28 \%$ of patients and venous ulceration in $12 \%$ of patients. Cosmetic appearance was the commonest complaint, which favours with the other comparative studies. ${ }^{9}$

\section{CEAP Classification}

Most patients came to the hospital to seek treatment, had one or the other complications of varicose veins (62\%); $38 \%$ of the patients had only prominent veins which belong to class II.

\section{Limb Involvement}

In the present study right limb involvement 38\%, left limb involvement $52 \%$ was noted. Bilateral limb involvement was seen in $10 \%$ of patients. The cause for the increased incidence of left side is not known. This is probably because that the loaded left colon constantly compresses the left iliac veins, the left common iliac artery crossing over the left 
common iliac vein and the longer course traversed by the left iliac veins. This compares favourably with the study conducted by A.H.M. Dur, A.J.C. Mackaay et al. ${ }^{3}$

\section{Venous System Involved}

Long saphenous vein was involved in $98 \%$ of patients, the second commonest being perforators which were involved in $86 \%$ of patients. Short saphenous veins was involved in about $18 \%$ of cases. Majority of the patients has combined saphenofemoral and perforator involvement. Similar results were observed by Al-Mulhim et al. ${ }^{10}$

\section{Site of Incompetence}

Majority of the patients had combined saphenofemoral and perforator incompetence (70\%). Isolated perforator insufficiency was noted in only $2 \%$ of patients. Combined saphenofemoral, saphenopopliteal and perforator incompetence was seen in $14 \%$ of patients.

\section{Site of Perforator Incompetence}

$51.1 \%$ of the patients had multiple perforator incompetence. Patients who had multiple perforator incompetence had one or the other complications of varicose veins. Isolated above knee perforator incompetence was seen in only one patient, below knee perforator incompetence was seen in $32.5 \%$ of patients and isolated lower leg and ankle perforator incompetence was seen in $13.9 \%$ of patients.

\section{Investigations}

Apart from the routine investigations, all the patients underwent duplex ultrasound of the venous system of lower limbs. This investigation was required to accurately locate the perforator incompetence and to rule out deep venous thrombosis and to mark the site of perforator incompetence before surgery.

\section{Treatment}

Treatment of cases was dependent upon the individual cases. In patients with venous ulcers Bisgaard's method of treatment was followed till the ulcer heals and then the patient was subjected to further definitive treatment.

Incompetent saphenofemoral valve is tackled by Trendelenburg operation with flush ligation of saphenofemoral junction and stripping of long saphenous vein. In cases where passing the stripper was difficult due to excessive tortuosity, Multiple Stab Avulsion (MSA) was performed. Saphenopopliteal incompetence was tackled by saphenopopliteal junction ligation. Incompetent perforators were managed either by SFL/EFL or multiple stab avulsion. These procedures were done individually or in combination with other procedures depending on the venous system involved.

In this present study, Saphenofemoral Flush Ligation + Stripping (SFFL + STRP) was performed in $44 \%$ of patients, Saphenofemoral Flush Ligation + Stripping + Multiple Stab Avulsion (SFFL + STRP + MSA) was performed in $8 \%$ of patients, Saphenofemoral Flush Ligation + Stripping + Subfascial Ligation (SFFL + STRP + SFL) was performed in $28 \%$ of patients, Saphenofemoral Flush Ligation + Stripping + Saphenopopliteal Ligation (SFFL + STRP + SPL) was performed in $6 \%$ of patients, Saphenofemoral Flush Ligation + Stripping + Saphenopopliteal Ligation + Subfascial Ligation
$(\mathrm{SFFL}+\mathrm{STRP}+\mathrm{SPL}+\mathrm{SFL})$ was performed in $10 \%$ of patients, Saphenopopliteal Ligation (SPL) alone was performed in $2 \%$ of patients, Multiple Stab Avulsion (MSA) alone was performed in $2 \%$ of patients.

Skin grafting was done in 2 patients for venous ulcer.

\section{Complications}

Patients were observed for complications, both intraoperatively and postoperatively. Wound infection was observed in $14 \%$ of patients, Haematoma was observed in $8 \%$ of patients, Saphenous neuritis was observed in $8 \%$ of patients, Wound dehiscence was observed in $6 \%$ of patients, $4 \%$ of patients had Lymphorrhoea from the inguinal wound. None of our patients had Femoral vein injury, Femoral artery injury, Deep vein thrombosis or Pulmonary embolism.

Sutures were removed at 7 to 10 days. Patients were advised elastic compression stockings for 1 year postoperatively. Patients were followed for 6 months. None of the patients developed recurrence.

\section{CONCLUSION}

1. Our study shows that the prevalence of varicose veins of lower limbs is more in people of younger age group.

2. Family history of varicose veins of lower limb is an important risk factor in the development of lower limb varicose veins.

3. Occupations involving prolonged standing is an important predisposing factor in the development of lower limb varicose veins.

4. Varicose veins mainly involve the long saphenous system due to saphenofemoral and perforator incompetence.

5. Most of the patients had complications of varicose veins.

6. Duplex ultrasonography is the investigation of choice.

\section{Summary}

Total number of 50 patients of varicose veins were studied in detail and an analysis data has been presented with following conclusion.

1. Varicosity of the veins of the lower limb is a fairly common clinical entity.

2. In spite of dilated veins for years, majority of the patients $(62 \%)$ presented only after development of complications; $38 \%$ of the patients presented for cosmetic concern.

3. The disease is more prevalent in the age group of $20-50$ years.

4. The disease is more common in males (2.1: 1)

5. Occupation involving prolonged standing was a major contributing factor in $56 \%$ of patients.

6. Hereditary factors play an important role in the development of varicose veins.

7. Involvement of long saphenous vein is noted in $98 \%$ of patients and short saphenous vein in $18 \%$ of patients.

8. Perforator incompetence was noted in $86 \%$ of patients.

9. Left side is involved more than right side.

10. Primary varicosities are much more common than secondary varicosities.

11. Adequate history and thorough clinical examination of the varicose veins is valuable in diagnosing varicose veins.

12. Duplex ultrasound is the most sensitive and specific investigation required to diagnose varicose veins. 
13. Doppler examination of venous system is a reasonable option when duplex ultrasound facility is not available.

14. Surgery is the primary modality of the treatment. Most common surgery performed is saphenofemoral flush ligation with stripping.

15. Bisgaard's method of treatment is effective against healing of venous ulcers.

16. Complications due to surgery were mainly wound infection, wound dehiscence, haematoma formation, lymphorrhoea and saphenous neuritis.

17. Mortality was nil in this study.

18. None of the patients had recurrence.

19. The procedures followed enable the patient to lead near normal life after the surgery.

\section{REFERENCES}

[1] Lam EY, Giswold ME, Moneta GL. Venous and lymphatic disease. $8^{\text {th }}$ edn. Chapter 23, Schwartz's principles of surgery 2005:808-33.

[2] Salaman RA, Salaman JH. Improving the preoperative assessment of varicose veins. $\mathrm{Br} \quad \mathrm{J}$ Surg 1997;84(12):1748.

[3] Dur AHM, Mackaay AJC. Duplex assessment of clinically diagnosed venous insufficiency. Br J surg 1992;79:155-61.

[4] Lagattolla NRF, Burnand KG, Sarin S. Duplex ultrasonography for assessment of venous valvular function of the lower limb. Br j Surg 1995;82(6):855-6.

[5] Fegan WG, Klime AL. The cause of varicosity in superficial veins of lower limb. $\mathrm{Br} \quad \mathrm{j}$ Surg 1972;59(10):798-801.

[6] Ratkal C. Thesis on clinical pathological study of varicose veins of the lower limb. University of Mysore 1980.
[7] Komsuoğlu B, Göldeli O, Kulan K, et al. Prevalence and risk factors of varicose veins in an elderly population. Gerontology 1994;40(1):25-31.

[8] Rudofsky G. Epidemiology and pathophysiology of primary varicose veins. Langenbecks Arc Chir 1988;(Suppl 2):139-44.

[9] O'Shaughnessy M, Rahall E, Walsh TN, et al. Surgery in the treatment of varicose veins. Ir Med J 1989;82(2):54-5.

[10] Al-Mulhim AS, El-Hoseiny $\mathrm{H}, \mathrm{Al}$-Mulhim $\mathrm{FM}$, et al. Surgical correction of main stem reflux in the superficial venous system: does it improve the blood flow of incompetent perforating veins? World J surg 2003;27(1):793-6.

[11] Sahu S, Bhushan S, Sachan P. Clinco-Anatomical and radiological study of varicose veins of lower limb and their management outcomes. The Internet Journal of Surgery 2012;28(2)1-9.

[12] Hagmuller GW. Complications in surgery of varicose veins. Langenbecks Arch Chir Suppl Kongressbd 1992:470-4.

[13] Teruya TH, Ballard JL. New approaches for the treatment of varicose veins. Surg Clin N Am 2004;84(5):1397-417.

[14] Chang CJ, Chua JJ. Endovenous laser photocoagulation (EVLP) for varicose veins. Lasers surg Med 2002;31(4):257-62.

[15] Gillespie D. Superficial varicose veins: Therapeutic options. In: Surgical management of venous diseases. $1^{\text {st }}$ edn. Williams and Wilkins, a waverly company 1997;25:373-90. 